\title{
Effect of combined therapy of diabinese and nicotinic acid on liver enzymes in rabbits with dithizone-induced diabetes
}

This article was published in the following Dove Press journal:

Journal of Experimental Pharmacology

7 October 2010

Number of times this article has been viewed

\section{Comfort C Monago' \\ Frank Onwuka' \\ Erhabor Osaro²}

'Departments of Biochemistry and ${ }^{2} \mathrm{Haematology}$ and Immunology, University of Port Harcourt, Choba, Rivers State, Nigeria

Correspondence: Erhabor Osaro Blood Sciences Department, Royal Bolton Hospital, Bolton, Greater Manchester, UK Tel +447932363219

Email n_osaro@yahoo.com

\begin{abstract}
The effects of diabinese, a known antidiabetic drug, and the combined effects of diabinese and nicotinic acid, a vitamin and antilipidemic drug, were studied in rabbits with dithizone-induced diabetes. Side effects of diabinese include hypoglycemia and liver toxicity. Dithizone was used to induce partial experimental diabetes and to increase blood glucose significantly $(P<0.05)$ by $31.3 \%, 23.5 \%, 19.5,24.7 \%$, and $23.9 \%$ in groups A (single therapy of diabinese $10 \mathrm{mg} / \mathrm{kg}$ body weight), B (10 mg of diabinese and nicotinic acid $150 \mathrm{mg} / \mathrm{kg}), \mathrm{C}(10 \mathrm{mg}$ diabinese and nicotinic acid $200 \mathrm{mg} / \mathrm{kg}$ ), D (10 mg diabinese and nicotinic acid $250 \mathrm{mg} / \mathrm{kg}$ ) and E control (distilled water $5 \mathrm{~mL}$ ), respectively. Dithizone administration also increased bilirubin, alkaline phosphatase (ALP), aspartate aminotransferase (AST), and alanine aminotransferase (ALT) levels by $28.9 \%-35.6 \%$, $41.2 \%-54.8 \%, 40.1 \%-46.1 \%$, and $60.9 \%-68.4 \%$, respectively. Diabinese monotherapy reduced bilirubin levels, while combined therapy reduced glucose, ALP, AST, and ALT levels more than single therapy. Reduction from the hyperglycemic level 48 hours after drug administration was $20.0 \%, 24.6 \%, 41.0 \%$, and $42.0 \%$ for groups A, B, C, and D, respectively, and was concentrationdependent. Also, combined therapy produced a significant $(P<0.05)$ decrease in AST and ALT levels, especially at 72 hours after drug administration, but did not affect ALP levels. No significant changes in glucose, bilirubin, ALP, AST, and ALT levels were observed in Group E (control). This study shows that liver toxicity and the hypoglycemic side effects of diabinese could be managed by the concomitant administration of nicotinic acid.
\end{abstract}

Keywords: dithizone-induced diabetes, diabinese, nicotinic acid, liver enzymes

\section{Introduction}

An association exists between diabetes and liver injury. ${ }^{1}$ Liver pathology in diabetics is similar to that seen in alcoholic liver disease, ${ }^{2}$ including fatty liver, ${ }^{3}$ fibrosis, and cirrhosis. ${ }^{4-6}$ Elevated serum aspartate (AST) and alanine aminotransferase (ALT) levels, ${ }^{7-9}$ and sometimes gamma glutamyl transferase $(\mathrm{GGT})^{10}$ are frequently found in both humans and experimental models of diabetes. ${ }^{11}$

Sulfonylureas have been used as first-line oral antihyperglycemic agents for Type 2 diabetes since 1954. Hepatotoxicity of antidiabetic drugs has been reported. ${ }^{12}$ Other antidiabetic drugs associated with severe liver disease include acarbose ${ }^{13,14}$ and troglitazone. ${ }^{15,16}$ Pioglitazone is effective in reducing triglycerides, and does not cause hypoglycemia, liver impairment, or rhabdomyolysis. ${ }^{17}$ Sulfonylureas have significant side effects, including hypoglycemia and weight gain (typically $4-6 \mathrm{~kg}$ ). ${ }^{18,19}$ They have no effects on lipids. This lack of benefit for protection against cardiovascular complications may be related to the fact that these agents cause hyperinsulinemia, which is associated with the metabolic syndrome..$^{20}$ There are also drug interactions associated 
with the sulfonylureas, including with drugs that increase or decrease glucose or insulin (which would interact with all oral antihyperglycemic agents) and drugs that increase their renal excretion, hepatic metabolism, or displace them from proteinbinding sites. ${ }^{21}$ Diabetic patients receiving these drugs should be monitored closely for these adverse effects.

Many drugs are known antilipolytic substances, and include statins, fibrates, bile acid sequestrants, cholesterol absorption inhibitors, and niacin (nicotinic acid). ${ }^{22,23}$ Of the available agents, nicotinic acid (vitamin $\mathrm{B}_{3}$ ) has the most powerful effect on dyslipidemia. High-dose statin therapy is associated with persistent elevations in ALT, AST, or both. ${ }^{24}$ Interestingly, the risk does not increase when nicotinic acid is combined with a statin, which has been confirmed in clinical studies. ${ }^{25,26}$

Multiple studies have investigated the effects of nicotinic acid on insulin resistance. One retrospective study suggested that the use of moderate doses of nicotinic acid may play a role in the control of diabetes. Nicotinic acid and nicotinamide overload have been reported to impair glucose tolerance and induce insulin resistance. ${ }^{27,28}$ Like statins, nicotinic acid is a known antilipidemic drug, and has been shown to be effective in treating diabetic dyslipidemia in the presence of aggressive oral hypoglycemic agents. ${ }^{29}$ There is a paucity of data on administration of nicotinic acid in combination with the antidiabetic drug, diabinese, in the management of diabetes and treatment-associated liver disease. The aim of this study was to investigate the use of nicotinic acid in combination with diabinese for the management of diabetes and associated liver disease in rabbits.

\section{Materials and methods Animals}

Five groups ( $n=3$ each) of healthy male albino rabbits with an average weight of $0.2-0.3 \mathrm{~kg}$ were used. Availability of food, water, ambient temperature, and proper ventilation were maintained throughout the study. All rabbits were confirmed to have normal glucose levels before induction of diabetes. The rabbits were treated according to the ethical guidelines of the Animal Center, University of Port Harcourt, Choba, and the experimental protocol was approved by the Animal Studies Committee of the University of Port Harcourt, Nigeria. Diabetes was induced by intraperitoneal injection of dithizone $5 \mathrm{mg} / \mathrm{kg}$ body weight. Seventy-two hours was allowed for full development of diabetes. After 72 hours, hyperglycemic glucose levels were determined.

\section{Drug administration}

Oral administration of diabinese or chlorpropamide (Pfizer, NewYork, NY) and/or nicotinic acid (Light and Co., Ltd, St. Louis, $\mathrm{MO}$ ) were given to groups A, B, C, and D. Group A was given diabinese $10 \mathrm{mg} / \mathrm{kg}$. Group B was given diabinese $10 \mathrm{mg} /$ $\mathrm{kg}+$ nicotinic acid $150 \mathrm{mg} / \mathrm{kg}$. Group $\mathrm{C}$ was given diabinese $10 \mathrm{mg} / \mathrm{kg}+$ nicotinic acid $200 \mathrm{mg} / \mathrm{kg}$. Group D was given diabinese $10 \mathrm{mg} / \mathrm{kg}+$ nicotinic acid $250 \mathrm{mg} / \mathrm{kg}$. Group E (control) rabbits became diabetic, but were given $5 \mathrm{~mL}$ of distilled water.

\section{Blood collection and analysis}

Blood was drawn before and after dithizone injection. Further collection of blood was done at 24,48 , and 72 hours after oral administration of diabinese and nicotinic acid. All parameters were analyzed using Reflotron (a modern discrete chemistry autoanalyzer; Roche, Mannheim, Germany). Blood glucose levels were determined using the glucose oxidase method described by Trinder, ${ }^{30}$ and bilirubin and alkaline phosphatase (ALP) were analyzed using the methods described by Steihi ${ }^{31}$ and Heins. ${ }^{32}$ AST and ALT levels were determined using the method described by Reitman and Frankel. ${ }^{33}$

\section{Statistical analysis}

Statistical analysis was carried out using the Statistical Package for Social Sciences (version 10; SPSS Inc., Chicago, IL). Data are expressed as mean \pm standard deviation (SD). Descriptive analysis of percentages of continuous variables is reported. Comparisons were assessed using means and analysis of variance testing. A $P$ value of $<0.05$ was considered to be statistically significant for all statistical comparisons.

\section{Results}

\section{Effects of treatment on glucose levels}

Dithizone significantly increased glucose levels within the range $19.5 \%-31.3 \%$ in all treatment groups, with no significant difference between groups A, B, C, and D at 24 hours regardless of whether diabinese was administered as monotherapy or in combination with nicotinic acid. However, after 48 hours, there was a significant decrease in glucose levels in all groups. Rabbits administered the combination of diabinese and the highest dose of nicotinic acid showed the most significant decrease in blood glucose levels (by 42\%). Diabinese without nicotinic acid (Group A) produced the least decrease (20\%). The results also showed a significant reduction in blood glucose as the concentration of nicotinic acid was increased. We observed a $20.0 \%, 24.6 \%, 41.0 \%$, and $42.0 \%$ reduction in blood glucose at 48 hours after administration of diabinese and nicotinic acid for groups A, B, C, and D, respectively. Group E did not show any reduction in glucose levels, as shown in Table 1. 
Table I Effects of diabinese and nicotinic acid on glucose levels in rabbits with dithizone-induced diabetes

\begin{tabular}{|c|c|c|c|c|c|}
\hline \multirow[t]{2}{*}{ Study groups } & \multirow{2}{*}{$\begin{array}{l}\text { Normal glucose levels pre- } \\
\text { induced diabetes (mg/dL) }\end{array}$} & \multirow{2}{*}{$\begin{array}{l}\text { Glucose levels } 72 \text { hours post- } \\
\text { induced diabetes }(\mathrm{mg} / \mathrm{dL})\end{array}$} & \multicolumn{3}{|c|}{ Hours after administration of drugs } \\
\hline & & & 24 & 48 & 72 \\
\hline $\begin{array}{l}\text { Group A (diabinese } \\
10 \mathrm{mg} / \mathrm{kg} \text { ) }\end{array}$ & $104.7 \pm 2.2^{c}$ & $149.7 \pm 5.13^{c}$ & $110.0 \pm 1.00^{c}$ & $105.3 \pm 0.88^{c, a}$ & $102.9 \pm 0.10^{c, a, b}$ \\
\hline $\begin{array}{l}\mathrm{d} / \mathrm{f} \text { from diabetic } \\
\text { level (\%) }\end{array}$ & 31.3 & 100 & 36.3 & 20.0 & 32.2 \\
\hline $\begin{array}{l}\text { Group B (diabinese } \\
10 \mathrm{mg}+\text { nicotinic acid } \\
150 \mathrm{mg} / \mathrm{kg} \text { ) }\end{array}$ & $108.3 \pm 1.16^{\mathrm{d}}$ & $14 \mid .3 \pm 2.08^{d}$ & $102.3 \pm 2.09^{d}$ & $103.5 \pm 0.5 I^{d, a}$ & $100.6 \pm 0.53^{\mathrm{d}, \mathrm{a}, \mathrm{b}}$ \\
\hline $\begin{array}{l}\mathrm{d} / \mathrm{f} \text { from diabetic } \\
\text { level (\%) }\end{array}$ & 23.5 & 100 & 27.7 & 26.6 & 29.1 \\
\hline $\begin{array}{l}\text { Group C (diabinese } \\
10 \mathrm{mg}+\text { nicotinic acid } \\
200 \mathrm{mg} / \mathrm{kg} \text { ) }\end{array}$ & $103.0 \pm 1.00^{e}$ & $146.7 \pm 3.52^{\mathrm{e}}$ & $91.3 \pm 2.52^{\mathrm{e}}$ & $88.3 \pm 0.58^{e, a}$ & $85.2 \pm 0.35^{e, a, b}$ \\
\hline $\begin{array}{l}\mathrm{d} / \mathrm{f} \text { from diabetic } \\
\text { level (\%) }\end{array}$ & 19.5 & 100 & 47.5 & 40.0 & 41.8 \\
\hline $\begin{array}{l}\text { Group D (diabinese } \\
10 \mathrm{mg}+\text { nicotinic acid } \\
250 \mathrm{mg} / \mathrm{kg} \text { ) }\end{array}$ & $107.3 \pm 2.52^{\vee}$ & $142.0 \pm 4.03^{\vee}$ & $86.3 \pm 1.53^{v}$ & $82.3 \pm 0.58^{\mathrm{v}, \mathrm{a}}$ & $81.2 \pm 0.76^{\mathrm{va,b}}$ \\
\hline $\begin{array}{l}\mathrm{d} / \mathrm{f} \text { from diabetic } \\
\text { level (\%) }\end{array}$ & 24.7 & 100 & 40.0 & 42.1 & 42.9 \\
\hline $\begin{array}{l}\text { Group E (distilled } \\
\text { water } 5 \mathrm{~mL} \text { ) }\end{array}$ & $106.8 \pm 2.12^{\mathrm{m}}$ & $141.1 \pm 1.13^{\mathrm{m}}$ & $144 \pm 1.12^{\mathrm{m}}$ & $146.6 \pm 0.99^{\mathrm{m}, \mathrm{a}}$ & $146.0 \pm 2.00^{m, a, b}$ \\
\hline $\begin{array}{l}\mathrm{d} / \mathrm{f} \text { from diabetic } \\
\text { level (\%) }\end{array}$ & 24.3 & 100 & 2.6 & 3.9 & 3.5 \\
\hline
\end{tabular}

Note: Values represent mean \pm standard error of mean of three samples in a group $(n=3)$. Statistical analysis was done using analysis of variance. Values were considered significant at $P<0.05$ and LSD was used to compare the means. Values with the same superscript are significant.

\section{Effects of treatment on bilirubin levels}

Dithizone significantly increased bilirubin levels by $28.9 \%-35.6 \%$. There was a significant reduction in bilirubin in all treatment groups except for the control group. Single therapy with diabinese reduced bilirubin levels more than combined therapy. Thus, the reduction in Group A (diabinese without nicotinic acid) was $40.0 \%, 38.1 \%$, and $20.9 \%$ after 24,48 , and 72 hours, respectively, after diabinese administration for Group B (diabinese + nicotinic acid $150 \mathrm{mg} / \mathrm{kg}$ ), the reduction was $27.8 \%, 30.8 \%$, and $22.0 \%$, respectively. Increasing concentrations of nicotinic acid in combination with diabinese produced a significant reduction of bilirubin. In Group D (treated with diabinese + nicotinic acid $250 \mathrm{mg} / \mathrm{kg}$ ), the reduction was $40.0 \%, 26.7 \%$, and $38.9 \%$, respectively, compared with $28.0 \%, 28.3 \%$, and $29.0 \%$ for Group C at 24,48 , and 72 hours after drug administration, as shown in Table 2.

\section{Effects of treatment on ALP levels}

Dithizone significantly increased ALP levels by $41.2 \%-54.8 \%$ three days following intraperitoneal injection. Groups A to D showed a significant reduction in ALP levels at 24, 48, and 72 hours after both diabinese alone and in combination with nicotinic acid. Increasing concentrations of nicotinic acid did not affect ALP levels except after 24 hours, when there was a significant decrease in levels of this enzyme as the concentration of nicotinic acid increased. The reduction was $55.5 \%, 59.1 \%, 52.5 \%$, $54.0 \%$, and $0.98 \%$, respectively, for groups A, B, C, D, and $\mathrm{E}$, as shown in Table 3.

\section{Effects of treatment on AST levels}

Dithizone administration resulted in a significant increase in AST levels from a range of 35.7-39.2 U/L to 62.0-71.0 U/L. AST levels were significantly reduced as the time since induction of diabetes increased, but increased significantly at 24-72 hours. Seventy-two hours after dithizone administration, AST levels decreased significantly as the concentration of nicotinic acid was increased. Levels were significantly reduced by diabinese and nicotinic acid combination therapy (Groups B, C, and D) than on diabinese alone (Group A). The ranges of the reductions were $36.3 \%-41.2 \%, 26.3 \%-31.8 \%$, $24.5 \%-34.9 \%$, and $35.3 \%-36.0 \%$ for groups A, B, C, and D, respectively, as shown in Table 4.

\section{Effects of treatment on ALT levels}

Dithizone administration produced an increase in ALT levels in groups A, B, C, and D by a range of $60.9 \%-68.4 \%$. 
Table 2 Effects of diabinese and nicotinic acid on bilirubin levels in rabbits with dithizone-induced diabetes

\begin{tabular}{|c|c|c|c|c|c|}
\hline \multirow[t]{2}{*}{ Study groups } & \multirow{2}{*}{$\begin{array}{l}\text { Normal bilirubin level } \\
\text { (mg/dL) pre-induced } \\
\text { diabetes }\end{array}$} & \multirow{2}{*}{$\begin{array}{l}\text { Bilirubin levels ( } \mathrm{mg} / \mathrm{dL}) \\
72 \text { hours post-induced } \\
\text { diabetes }\end{array}$} & \multicolumn{3}{|c|}{ Hours after administration of drugs } \\
\hline & & & 24 & 48 & 72 \\
\hline $\begin{array}{l}\text { Group A (diabinese } \\
10 \mathrm{mg} / \mathrm{kg} \text { ) }\end{array}$ & $0.80 \pm 0.02^{f}$ & $1.15 \pm 0.04^{f}$ & $0.69 \pm 0.03^{b, c, f, g}$ & $0.7 \mathrm{I} \pm 0.0 \mathrm{I}^{\mathrm{a}, \mathrm{b}, \mathrm{f}, \mathrm{fg}}$ & $0.8 \mathrm{I} \pm 0.02^{\mathrm{b}, \mathrm{c}, \mathrm{fg} g}$ \\
\hline $\begin{array}{l}\mathrm{d} / \mathrm{f} \text { from diabetic } \\
\text { level }(\%)\end{array}$ & 31.5 & 100 & 40.0 & 38.1 & 20.9 \\
\hline $\begin{array}{l}\text { Group B (diabinese } \\
10 \mathrm{mg}+\text { nicotinic } \\
\text { acid } 150 \mathrm{mg} / \mathrm{kg} \text { ) }\end{array}$ & $0.82 \pm 0.14^{r}$ & $1.14 \pm 0.0^{r}$ & $0.83 \pm 0.03^{b, c, r}$ & $0.79 \pm 0.02^{\mathrm{b}, \mathrm{a}, \mathrm{r}}$ & $0.89 \pm 0.03^{r, b, c}$ \\
\hline $\begin{array}{l}\mathrm{d} / \mathrm{f} \text { from diabetic } \\
\text { level (\%) }\end{array}$ & 28.9 & 100 & 27.8 & 30.8 & 22.0 \\
\hline $\begin{array}{l}\text { Group C (diabinese } \\
10 \mathrm{mg}+\text { nicotinic } \\
\text { acid } 200 \mathrm{mg} / \mathrm{kg} \text { ) }\end{array}$ & $0.84 \pm 0.06$ & $1.25 \pm 0.02^{i}$ & $0.90 \pm 0.03^{b, c, l, g}$ & $0.90 \pm 0.02^{\mathrm{a}, \mathrm{b}, \mathrm{lg}}$ & $0.77 \pm 0.0 \mathrm{I}^{\mathrm{b}, \mathrm{c}, \mathrm{i}, \mathrm{g}}$ \\
\hline $\begin{array}{l}\mathrm{d} / \mathrm{f} \text { from diabetic } \\
\text { level (\%) }\end{array}$ & 32.8 & 100 & 28.0 & 28.0 & 39.4 \\
\hline $\begin{array}{l}\text { Group D (diabinese } \\
10 \mathrm{mg}+\text { nicotinic } \\
\text { acid } 250 \mathrm{mg} / \mathrm{kg} \text { ) }\end{array}$ & $0.80 \pm 0.13^{d}$ & $1.20 \pm 0.02^{\mathrm{d}}$ & $0.72 \pm 0.02^{b, c, d, g}$ & $0.88 \pm 0.02^{\mathrm{b}, \mathrm{a}, \mathrm{d}}$ & $0.83 \pm 0.0^{b, c, d, g}$ \\
\hline $\begin{array}{l}\mathrm{d} / \mathrm{f} \text { from diabetic } \\
\text { level (\%) }\end{array}$ & 35.6 & 100 & 40.0 & 26.7 & 38.9 \\
\hline $\begin{array}{l}\text { Group E (distilled } \\
\text { water } 5 \mathrm{~mL} \text { ) }\end{array}$ & $0.81 \pm 0.0 I^{x}$ & $1.21 \pm 0.12^{x}$ & $1.19 \pm 0.10$ & $1.20 \pm 0.02$ & $1.21 \pm 0.05$ \\
\hline $\begin{array}{l}d / f \text { from diabetic } \\
\text { level (\%) }\end{array}$ & 35.5 & 100 & 1.5 & 0.09 & 0.00 \\
\hline
\end{tabular}

Note: Values represent mean \pm standard error of mean of three samples in a group $(n=3)$. Statistical analysis was done using analysis of variance. Values were considered significant at $P<0.05$ and LSD was used to compare the means. Values with the same superscript are significant.

Increasing nicotinic acid concentrations resulted in a decrease in ALT levels, which was not significant until 72 hours after administration of the various combined therapies. When single therapy was compared with combined therapy, there was a significant decrease in ALT levels only with diabinese alone, especially at 24 hours. We observed reductions in ALT levels of $72.1 \%, 68.9 \%, 65.9 \%, 68.9 \%$, and $0.9 \%$ for groups A, B, C, D, and E, respectively. Group E showed no significant variation in ALT levels throughout the study. The effects of diabinese and nicotinic acid on ALT levels in dithizone-induced diabetic rabbits are shown in Table 5.

\section{Discussion}

In this study, dithizone, a known metal chelator ${ }^{34}$ and antidiabetic agent, was used to induce partial diabetes. Partial destruction of islets in dogs, cats, and rats treated with dithizone has been demonstrated. ${ }^{35}$ In the present study, dithizone was used to induce experimental diabetes by raising the blood glucose level significantly by $19.5 \%-31.3 \%$. Previous research has indicated that very low concentrations of dithizone can be used for differential staining of islets for transplantation. ${ }^{36}$
In Rerup's review, ${ }^{37}$ it was reported that dithizoneinduced diabetes shows similar phasic fluctuations along with selective damage to insulin-producing cells, and that phasic glycemia comprises initial hyperglycemia, followed by hypoglycemia, and, finally, permanent hyperglycemia. We achieved phasic glycemia in the present study by allowing the development of diabetes for 72 hours. A previous study used alloxan to induce experimental diabetes. ${ }^{37}$ Development of diabetes was shown to be connected with its ability to chelate metals like zinc. Insulin-producing cells are devoid of zinc in dithizone-induced diabetes of long duration with high hyperglycemia. ${ }^{38}$

Increasing concentrations of nicotinic acid decreased glucose levels. However, because one of the side effects of sulphonylureas (including diabinese) is excessive hypoglycemia, excessive administration of nicotinic acid may not be advisable because combined therapy has the potential to decrease glucose levels excessively, and moreso than diabinese alone. The findings of this study showed that nicotinic acid at a very low concentration can be used in combination with diabinese in the management of patients with diabetes. This is evident from the results of our study wherein diabinese monotherapy achieved a reduction in 
Table 3 Effects of diabinese and nicotinic acid on alkaline phosphatase levels in rabbits with dithizone-induced diabetes

\begin{tabular}{|c|c|c|c|c|c|}
\hline \multirow[t]{2}{*}{ Study groups } & \multirow{2}{*}{$\begin{array}{l}\text { ALP level (U/L) pre-induced } \\
\text { diabetes (normal level) }\end{array}$} & \multirow{2}{*}{$\begin{array}{l}\text { ALP level (U/L) } 72 \text { hours post- } \\
\text { induced diabetes }\end{array}$} & \multicolumn{3}{|c|}{ Hours after administration of drugs } \\
\hline & & & 24 & 48 & 72 \\
\hline $\begin{array}{l}\text { Group A (diabinese } \\
10 \mathrm{mg} / \mathrm{kg} \text { ) }\end{array}$ & $121.0 \pm 1.00^{\mathrm{a}}$ & $226.0 \pm 24.25^{a}$ & $101.0 \pm 2.00^{\mathrm{a}, \mathrm{b}, \mathrm{d}}$ & $98.3 \pm 1.53^{\mathrm{a}, \mathrm{d}}$ & $102.5 \pm 4.07^{\mathrm{a}}$ \\
\hline $\begin{array}{l}\mathrm{d} / \mathrm{f} \text { from diabetic } \\
\text { level }(\%)\end{array}$ & 47.5 & 100 & 55.5 & 57.8 & 54.5 \\
\hline $\begin{array}{l}\text { Group B (diabinese } \\
10 \mathrm{mg}+\text { nicotinic } \\
\text { acid } 150 \mathrm{mg} / \mathrm{kg} \text { ) }\end{array}$ & $123.3 \pm 12.58^{\vee}$ & $215.0 \pm 18.03^{v}$ & $88.7 \pm 1.53^{v, c, b, d}$ & $100.0 \pm 2.00^{\mathrm{b}, \mathrm{d}}$ & $100.3 \pm 1.13^{v}$ \\
\hline $\begin{array}{l}\mathrm{d} / \mathrm{f} \text { from diabetic } \\
\text { level }(\%)\end{array}$ & 43.8 & 100 & 59.1 & 54.5 & 54.4. \\
\hline $\begin{array}{l}\text { Group C (diabinese } \\
10 \mathrm{mg}+\text { nicotinic } \\
\text { acid } 200 \mathrm{mg} / \mathrm{kg} \text { ) }\end{array}$ & $126.7 \pm 8.33^{\mathrm{m}}$ & $213.0 \pm 3.6 \mathrm{I}^{\mathrm{m}}$ & $98.7 \pm 3.06^{\mathrm{m}, c, d}$ & $101.0 \pm 1.00^{\mathrm{m}}$ & $98.0 \pm 1.00^{\mathrm{m}, \mathrm{b}}$ \\
\hline $\begin{array}{l}\mathrm{d} / \mathrm{f} \text { from diabetic } \\
\text { level }(\%)\end{array}$ & 41.6 & 100 & 54.0 & 52.3 & 54.1 \\
\hline $\begin{array}{l}\text { Group D (diabinese } \\
10 \mathrm{mg}+\text { nicotinic } \\
\text { acid } 250 \mathrm{mg} / \mathrm{kg} \text { ) }\end{array}$ & $123.0 \pm\left. 7.2\right|^{x}$ & $222.7 \pm 3.52^{x}$ & $108.3 \pm 3.5^{x, b, d}$ & $104.0 \pm 2.65^{x, b}$ & $96.4 \pm 1.22^{x, b}$ \\
\hline $\begin{array}{l}\mathrm{d} / \mathrm{f} \text { from diabetic } \\
\text { level (\%) }\end{array}$ & 54.8 & 100 & 52.5 & 53.2 & 57.2 \\
\hline $\begin{array}{l}\text { Group E (distilled } \\
\text { water } 5 \mathrm{~mL} \text { ) }\end{array}$ & $120.0 \pm 6.0^{9}$ & $204.1 \pm 2.12^{q}$ & $202.1 \pm 5.12$ & $203.4 \pm 6.32$ & $202.0 \pm 4.90$ \\
\hline $\begin{array}{l}\mathrm{d} / \mathrm{f} \text { from diabetic } \\
\text { level (\%) }\end{array}$ & 41.2 & 100 & 0.98 & 0.49 & 0.98 \\
\hline
\end{tabular}

Note: Values represent mean \pm standard error of mean of three samples in a group $(n=3)$. Statistical analysis was done using analysis of variance. Values were considered significant at $P<0.05$ and LSD was used to compare the means. Values with the same superscript are significant.

Abbreviation: ALP, alkaline phosphatase.

glucose levels of $36.3 \%$ and combined therapy of diabinese and nicotinic acid $150 \mathrm{mg} / \mathrm{kg}$ reduced glucose levels by $27.7 \%$ after 24 hours. It appears from our study that nicotinic acid at a dose of $150 \mathrm{mg} / \mathrm{kg}$ in combination with diabinese may be optimal in the management of diabetes in rabbits. When further reduction of blood glucose is required, higher concentrations of nicotinic acid can be introduced.

After injection of dithizone, 72 hours was allowed for full development of diabetes. Induction of diabetes with dithizone was similar to that induced by alloxan.39 Dithizone-induced diabetes also resulted in an increase in bilirubin, ALT, AST, and ALP levels by $28.9 \%-35.6 \%$, $60.9 \%-68.4 \%, 40.1 \%-46.1 \%$, and $41.6 \%-54.8 \%$, respectively. Consistent with previous reports indicating that diabetes correlates with liver disease and an associated increase in levels of liver enzymes in the blood is seen in both humans and experimental animal models, our study showed a significant increase in liver enzymes in rabbits with dithizone-induced diabetes. ${ }^{7,8,11}$

Previous studies have reported increased lipid peroxidation in the liver, kidney, and brain tissues of diabetic rats. ${ }^{40,41}$ This may be because the tissues contain relatively high concentrations of easily peroxidizable fatty acids. The diabetic liver showed relatively severe impairment in antioxidant capacity compared with that in the kidney. The increase in oxygen free radicals seen in diabetes could primarily be due to increased blood glucose levels which generate free radicals upon auto-oxidation, and secondarily due to the effects of diabetogenic agents, such as dithizone or alloxan. ${ }^{42}$ Increased lipid peroxidation impairs membrane function by decreasing membrane fluidity and changing the activity of membrane-bound enzymes. ${ }^{43}$ Its products (ie, lipid radicals and lipid peroxide) are harmful to cells in the body and are associated with high levels of these enzymes in diabetes. This may explain the increase in these enzymes found in dithizone-induced diabetes.

Findings by Debbie et $\mathrm{a} \mathrm{l}^{44}$ provide further support for the suggestion that obesity and diabetes are related to liver pathology. In adjusted models they showed that a one SD increase in body mass index was associated with a $0.46 \mathrm{U} / \mathrm{L}$ (95\% confidence interval [CI]: 0.16-0.75) increase in ALT and a $2.14 \mathrm{U} / \mathrm{L}(95 \% \mathrm{CI}$ : 0.99-3.30) increase in GGT. Similarly, results for a one SD increase in waist:hip ratio were 13.96 (95\% CI: 10.44-17.48) for ALT and 39.44 (95\% CI: 25.89-52.98) for GGT. In the present study, 
Table 4 Effects of diabinese and niacin on aspartate aminotransferase levels in rabbits with dithizone-induced diabetes

\begin{tabular}{|c|c|c|c|c|c|}
\hline \multirow[t]{2}{*}{ Study groups } & \multirow{2}{*}{$\begin{array}{l}\text { AST level (U/L) pre-induced } \\
\text { diabetes (normal level) }\end{array}$} & \multirow{2}{*}{$\begin{array}{l}\text { AST level (U/L) } 72 \text { hours } \\
\text { post-induced diabetes }\end{array}$} & \multicolumn{3}{|c|}{ Hours after administration of drugs } \\
\hline & & & 24 & 48 & 72 \\
\hline $\begin{array}{l}\text { Group A (diabinese } \\
10 \mathrm{mg} \text { ) }\end{array}$ & $39.3 \pm 2.89^{k}$ & $71.0 \pm 19.06^{k}$ & $45.1 \pm 1.05^{\mathrm{a}, \mathrm{c}, \mathrm{k}}$ & $45.1 \pm 0.2^{\mathrm{d}, \mathrm{e}, \mathrm{k}}$ & $41.2 \pm 0.10^{5, k}$ \\
\hline $\begin{array}{l}\mathrm{d} / \mathrm{f} \text { from diabetic } \\
\text { level (\%) }\end{array}$ & 46.1 & 100 & 36.3 & 36.3 & 42.3 \\
\hline $\begin{array}{l}\text { Group B (diabinese } \\
10 \mathrm{mg}+\text { niacin } \\
150 \mathrm{mg} / \mathrm{kg} \text { ) }\end{array}$ & $38.6 \pm 2.20^{y}$ & $63.0 \pm 5.87 y$ & $44.3 \pm 6.1^{c, y}$ & $46.1 \pm 1.6^{d, e, f, y}$ & $43.0 \pm 0.63^{\mathrm{s}, y}$ \\
\hline $\begin{array}{l}\mathrm{d} / \mathrm{f} \text { from diabetic } \\
\text { level (\%) }\end{array}$ & 40.1 & 100 & 31.2 & 26.3 & 31.8 \\
\hline $\begin{array}{l}\text { Group C (diabinese } \\
10 \mathrm{mg}+\text { niacin } \\
200 \mathrm{mg} / \mathrm{kg} \text { ) }\end{array}$ & $36.5 \pm 2.23^{v}$ & $62.2 \pm 19.60^{v}$ & $43.7 \pm 8.0^{a, c, v}$ & $47.1 \pm 0.10^{\mathrm{e}, \mathrm{f}}$ & $41.3 \pm\left. 0.5\right|^{s, v}$ \\
\hline $\begin{array}{l}\mathrm{d} / \mathrm{f} \text { from diabetic } \\
\text { level (\%) }\end{array}$ & 41.2 & 100 & 30.7 & 24.5 & 34.9 \\
\hline $\begin{array}{l}\text { Group D (diabinese } \\
10 \mathrm{mg}+\text { niacin } \\
250 \mathrm{mg} / \mathrm{kg} \text { ) }\end{array}$ & $35.7 \pm 5.75^{b}$ & $63.4 \pm 5.89^{\circ}$ & $41.3 \pm 1.26^{c, b}$ & $46.0 \pm 1.0^{\mathrm{d}, \mathrm{e}, \mathrm{f,b}}$ & $42.0 \pm\left. 0.0\right|^{\mathrm{s}, \mathrm{b}}$ \\
\hline $\begin{array}{l}\mathrm{d} / \mathrm{f} \text { from diabetic } \\
\text { level (\%) }\end{array}$ & 44.5 & 100 & 35.0 & 27.0 & 33.4 \\
\hline $\begin{array}{l}\text { Group E (distilled } \\
\text { water } 5 \mathrm{~mL} \text { ) }\end{array}$ & $36.2 \pm 3.80^{f}$ & $66.2 \pm 2.21^{f}$ & $66.0 \pm 2.21$ & $65.3 \pm 3.23$ & $65.9 \pm 2.41$ \\
\hline $\begin{array}{l}\mathrm{d} / \mathrm{f} \text { from diabetic } \\
\text { level (\%) }\end{array}$ & 45.5 & 100 & 0.3 & 1.4 & 0.5 \\
\hline
\end{tabular}

Note: Values represent mean \pm standard error of mean of three samples in a group $(n=3)$. Statistical analysis was done using analysis of variance. Values were considered significant at $P<0.05$ and LSD was used to compare the means. Values with the same superscript are significant.

Abbreviation: AST, aspartate aminotransferase.

there was a significant larger decrease $(P<0.05)$ in ALT with single therapy than with combined therapy 24 hours after drug administration. We observed a $72.1 \%, 68.9 \%$, $65.9 \%, 68.9 \%$, and $0.9 \%$ reduction from high ALT levels in groups A, B, C, D, and E, respectively, after 24 hours. This result suggests that the best way to decrease the increased ALT seen in diabetic rabbits is to allow the combination of diabinese and nicotinic acid therapy to act for a longer time. On the other hand, the AST level was reduced significantly $(P<0.05)$ more in rabbits who received combined therapy with diabinese and nicotinic acid (groups B, C, and D) than in rabbits who received diabinese alone (Group A) from 24-72 hours. These observations suggest that the increased ALT and AST levels observed in diabetes ${ }^{7,42}$ and associated with the use of antidiabetic drugs, ${ }^{12-14}$ including diabinese, can be reduced when diabinese is combined with nicotinic acid.

An increase in the concentration of nicotinic acid when combined with diabinese did not affect ALP levels, except after 24 hours when there was a significant decrease $(P<0.05)$ in levels of the enzyme as the concentration of nicotinic acid increased. A single $375 \mathrm{mg}$ dose of extended-release nicotinic acid given to patients with meals decreased serum ALP levels significantly from $107 \hat{\mathrm{A}} \pm 66 \mathrm{IU} / \mathrm{L}$ to $82 \hat{\mathrm{A}} \pm 46 \mathrm{IU} / \mathrm{L}(P<0.001) .{ }^{45}$ Similar results were observed in the present study with rabbits in which ALP decreased from diabetic levels in groups B, C, and D. After 48 hours, ALP levels were seen to decrease significantly with increasing nicotinic acid concentration. We observed ALP levels of $102.5 \pm 4.07,100.3 \pm 1.13$, $98.0 \pm 1.00$, and $96.4 \pm 1.22 \mathrm{U} / \mathrm{L}$ for groups $\mathrm{A}, \mathrm{B}, \mathrm{C}$, and D, respectively.

Nicotinic acid and statins are widely recognized as antilipidemic drugs. In controlled clinical trials, $0.3 \%-4.6 \%$ of patients receiving statins discontinued therapy because of adverse effects, mainly rash, musculoskeletal pain, asymptomatic increases in AST and/or ALT concentrations, and mild, nonspecific gastrointestinal disturbances. Increases in AST and ALT levels to more than three times the upper limit of normal occurring on at least two occasions were reported in $0.1 \%-3 \%$ of patients receiving statins for at least 11 months. These increases were generally dose-dependent but, importantly, were not associated with jaundice..$^{10}$ Similarly, in a previous report, a 12-week course of simvastatin therapy resulted in an increase in AST and ALT levels from a mean of $22.1 \pm 6.27 \mathrm{IU} / \mathrm{mL}$ to $32.85 \pm 8.33 \mathrm{IU} / \mathrm{mL}(P<0.001)$ 
Table 5 Effects of diabinese and niacin on alanine aminotransferase levels in rabbits with dithizone-induced diabetes

\begin{tabular}{|c|c|c|c|c|c|}
\hline \multirow[t]{2}{*}{ Study groups } & \multirow{2}{*}{$\begin{array}{l}\text { ALT level (U/U) pre-induced } \\
\text { diabetes (normal level) }\end{array}$} & \multirow{2}{*}{$\begin{array}{l}\text { ALT level }(U / U) 72 \text { hours } \\
\text { post-induced diabetes }\end{array}$} & \multicolumn{3}{|c|}{ Time after administration (hours) } \\
\hline & & & 24 & 48 & 72 \\
\hline $\begin{array}{l}\text { Group A } \\
\text { (diabinese } 10 \mathrm{mg} / \mathrm{kg} \text { ) }\end{array}$ & $32.0 \pm 2.82^{h}$ & $88.5 \pm 17.20^{h}$ & $25.0 \pm 2.49^{h, p}$ & $32.6 \pm 0.40^{h, p}$ & $29.0 \pm 0.2 \mathrm{I}^{\mathrm{h}}$ \\
\hline $\begin{array}{l}\mathrm{d} / \mathrm{f} \text { from } \\
\text { diabetic level (\%) }\end{array}$ & 64.6 & 100 & 72.1 & 64.1 & 67.1 \\
\hline $\begin{array}{l}\text { Group B (diabinese } \\
10 \mathrm{mg}+\text { niacin } \\
150 \mathrm{mg} / \mathrm{kg} \text { ) }\end{array}$ & $32.3 \pm 2.45^{s}$ & $106.0 \pm 6.00^{\mathrm{s}}$ & $33.7 \pm 2.65^{\mathrm{s}, \mathrm{p}}$ & $35.0 \pm 0.40^{\mathrm{spp}}$ & $32.3 \pm 1.17^{\mathrm{s,n}}$ \\
\hline $\begin{array}{l}\mathrm{d} / \mathrm{f} \text { from } \\
\text { diabetic level (\%) }\end{array}$ & 60.9 & 100 & 68.9 & 67.0 & 70.0 \\
\hline $\begin{array}{l}\text { Group C (diabinese } \\
10 \mathrm{mg}+\text { niacin } \\
200 \mathrm{mg} / \mathrm{kg} \text { ) }\end{array}$ & $35.0 \pm .00^{c}$ & $107.0 \pm 10.15^{c}$ & $37.4 \pm 0.78^{\mathrm{c}, \mathrm{p}}$ & $36.5 \pm 0.35^{c, p}$ & $33.8 \pm 0.16^{c}$ \\
\hline $\begin{array}{l}\text { d/f from } \\
\text { diabetic level (\%) }\end{array}$ & 67.3 & 100 & 65.9 & 65.9 & 68.5 \\
\hline $\begin{array}{l}\text { Group D (diabinese } \\
10 \mathrm{mg}+\text { niacin } \\
250 \mathrm{mg} / \mathrm{kg} \text { ) }\end{array}$ & $34.6 \pm 2.26^{8}$ & $107.5 \pm 1.95^{g}$ & $33.3 \pm 1.32^{g . p}$ & $34.60 \pm 0.3^{g . p}$ & $29.1 \pm 0.16^{8}$ \\
\hline $\begin{array}{l}\mathrm{d} / \mathrm{f} \text { from diabetic } \\
\text { level (\%) }\end{array}$ & 67.9 & 100 & 68.9 & 67.9 & 72.9 \\
\hline $\begin{array}{l}\text { Group E (distilled } \\
\text { water } 5 \mathrm{~mL} \text { ) }\end{array}$ & $33.2 \pm 2.31$ & $104.3 \pm 2.13$ & $105.2 \pm 3.11$ & $104.6 \pm 3.42$ & $105.5 \pm 2.73$ \\
\hline $\begin{array}{l}\mathrm{d} / \mathrm{f} \text { from } \\
\text { diabetic level (\%) }\end{array}$ & 68.4 & 100 & 0.9 & 0.3 & 1.2 \\
\hline
\end{tabular}

Note: Values represent mean \pm standard error of mean of three samples in a group $(n=3)$. Statistical analysis was done using ANOVA. Values were considered significant at $P<0.05$ and LSD was used to compare the means. Values with the same superscript are significant.

Abbreviation: ALT, alanine aminotransferase.

and $22.85 \pm 6.49 \mathrm{IU} / \mathrm{mL}$ to $31.56 \pm 9.18(P<0.001)$, respectively, after six weeks. ${ }^{25}$ The findings from this study show that nicotinic acid can be used conveniently not only in the management of diabetes-associated liver disease but also that nicotinic acid could be a safer alternative compared with statins, which have significant side effects.

An overview of data from the clinical trials, as well as postmarketing experience, indicates a very low incidence of elevated liver enzymes with prolonged-release nicotinic acid, either alone or in combination with a statin $(<1 \%)^{29,46}$ and with no increase in the incidence of myopathy when used in combination with a statin compared with statin therapy alone. ${ }^{46}$ In the present study, nicotinic acid decreased elevated AST and ALT levels in diabetic rabbits. Patients who received a combination of immediate-release nicotinic acid and simvastatin (mean daily doses $2.4 \mathrm{~g}$ and $13 \mathrm{mg}$, respectively) for three years showed no significant difference in the frequency of clinical or laboratory side effects compared with placebo. ${ }^{26}$ Measurement of liver transaminases and ALP at initiation, after six weeks of therapy, and every 4-6 months thereafter confirmed these findings. ${ }^{47}$

The available evidence relating to the use of nicotinic acid in diabetic patients is reassuring. Consequently, in view of these data, the 2004 American Diabetes Association recommendations for dyslipidemia management in adults with diabetes ${ }^{11}$ emphasize that low doses of nicotinic acid ( $\leq 2 \mathrm{~g}$ /day) may not have much of a detrimental effect on glycemic control, and that any deterioration may be easily remedied by adjustment of hypoglycemic medications. ${ }^{48}$ Thus, the overall consensus of this panel, based on the available data, is that nicotinic acid at clinically recommended doses $(\leq 2 \mathrm{~g} /$ day $)$ is an acceptable treatment option in patients with diabetes, as well as in patients with metabolic syndrome and at high risk of heart disease. A maximum nicotinic acid dose of $250 \mathrm{mg} / \mathrm{kg}$ was used in the present animal model.

Our study had several limitations. We investigated the effect of diabinese and nicotinic acid in dithizone-induced diabetes and associated liver disease characterized by an increase in liver enzymes. We now intend to investigate the effect of niacin alone on glucose metabolism and liver enzymes in a subsequent study. Our study investigated the short-term effects of combined diabinese and nicotinic acid therapy on liver enzymes and glucose metabolism. There is a need to monitor the long-term effects of this combined treatment on glucose metabolism and liver enzymes in diabetic rabbits. We did not investigate the effect of combined 
treatment with diabinese and nicotinic acid on liver pathology and on development of fatty liver.

The findings of our study show that the considerable elevation of liver enzymes in diabetes may be avoided by concomitant administration of nicotinic acid, a known antilipidemic drug. The combination of nicotinic acid and diabinese may have the potential to improve liver disease associated with both diabetes and the use of antidiabetic drugs.

\section{Disclosure}

The authors report no conflicts of interest in this work.

\section{References}

1. Lewis GF, Carpentier A, Khosrow A, Giacca A. Disordered fat storage and mobilization in the pathogenesis of insulin resistance and Type 2 diabetes. Endocrinol Rev. 2002;23:201-229.

2. Neuschwander-Tetri BA, Caldwell S. Nonalcoholic steatohepatitis: Summary of AASLD single topic conference. Hepatology. 2003;37:1202-1219.

3. Seppala-Lindroos A, Vehkavaara S, Hakkinen AM, et al. Fat accumulation in the liver is associated with defects in insulin suppression of glucose production and serum free fatty acids independent of obesity in normal men. J Clin Endocrinol Metab. 2002;87:3023-3028.

4. Daniel S, Ben-Menachem T, Vasudevan G, Ma D, Blumenkehl M. Prospective evaluation of unexplained chronic liver transaminase abnormalities in asymptomatic and symptomatic patients. Am J Gastroenterol. 1999;94:3010-3014.

5. Knobler H, Schihmanter R, Zifroni A, Finakel G, Schattner A. Increased risk of type 2 diabetes in no cirrhotic patients with chronic hepatitis C virus infection. Mayo Clin Proc. 2000;75:355-359.

6. Alba LM, Lindor K. Review article: Nonalcoholic fatty liver disease. Aliment Pharmacol Ther. 2003;17:977-986.

7. Erbey JR, Silberman C, Lydick E. Prevalence of abnormal serum alanine aminotransferase levels in obese patients and patients with Type 2 diabetes. Am J Med. 2000;109:588-590.

8. Baig NA, Herrine SK, Rubin R. Liver disease and diabetes mellitus. Clin Lab Med. 2001;21:193-207.

9. Vozarova B, Stefan N, Lindsay RS, et al. High alanine aminotransferase is associated with decreased hepatic insulin sensitivity and predicts the development of Type 2 diabetes. Diabetes. 2002;51:1889-1895.

10. Nakanishi N, Suzuki K, Tatara K. Serum gamma-glutamyltransferase and risk of metabolic syndrome and Type 2 diabetes in middle-aged Japanese men. Diabetes Care. 2004;27:1427-1432.

11. American Diabetes Association. Elevated alanine aminotransferase predicts new-onset Type 2 diabetes independently of classical risk factors, metabolic syndrome, and C-reactive protein in the West of Scotland Coronary Prevention Study. Diabetes. 2004;53: $2855-2860$.

12. Nakao NL, Gelb AM, Stenger RJ, Siegel JH. A case of chronic liver disease due to tolazamide. Gastroenterology. 1985;19:192-195.

13. Chitturi S, George J. Hepatotoxicity of commonly used drugs: Nonsteroidal anti-inflammatory drugs, antihypertensives, antidiabetic agents, anticonvulsants, lipid-lowering agents, psychotropic drugs. Semin Liver Dis. 2002;22:169-183.

14. Hsiao SH, Liao LH, Cheng PN, Wu TJ. Hepatotoxicity associated with acarbose therapy. Ann Pharmacother. 2006;40:151-154.

15. Faich GA, Moseley RH. Troglitazone (Rezulin) and hepatic injury. Pharmacoepidemiol Drug Saf. 2001;10:537-547.

16. Chojkier M. Troglitazone and liver injury: In search of answers. Hepatology. 2005;41:237-246.

17. Abe M, Kikuchi F, Okada K, Kaizu K, Matsumoto K. Efficacy of pioglitazone on Type 2 diabetic patients with hemodialysis. Diabetes Res Clin Pract. 2009;80:432-438.
18. DeFronzo RA. Pharmacologic therapy for Type 2 diabetes mellitus. Ann Intern Med. 1999;131:281-303.

19. Inzucchi SE. Oral antihyperglycemic therapy for Type 2 diabetes. JAMA. 2002;287:360-372.

20. Genuth S, Eastman R, Kahn R, et al; ADA American Diabetes Association. Implications of the United Kingdom Prospective Diabetes Study. Diabetes Care. 2003;26 Suppl:S28-S32.

21. Wickersham RM, Novak KK, editors. Drug Facts and Comparisons. St Louis, MO: Wolter Kluwer; 2006.

22. Bays HE, Moore PB, Drehobl MA, et al; The Ezetimibe Study Group. Effectiveness and tolerability of ezetimibe in patients with primary hypercholesterolemia: Pooled analysis of two Phase II studies. Clin Ther. 2001;23:1209-1230.

23. Dujovne CA, Ettinger MP, McNeer JF, et al; The Ezetimibe Study Group. Efficacy and safety of a potent new selective cholesterol absorption inhibitor, ezetimibe, in patients with primary hypercholesterolemia. Am J Cardiol. 2002;90:1092-1097.

24. LaRosa JC, Grundy SM, Waters DD, et al; Treating to New Targets (TNT) Investigators. Intensive lipid lowering with atorvastatin in patients with stable coronary disease. $N$ Engl J Med. 2005;352: $1425-1435$.

25. Udawat H, Goyal RK. Lipid-lowering effect of simvastatin in patients of Type 2 diabetes mellitus. Indian Heart J. 2001;53:172-176.

26. Chrysant SG, Ibrahim M. Niacin-ER/statin combination for the treatment of dyslipidemia: Focus on low high-density lipoprotein cholesterol. J Clin Hypertens. 2006;8:493-499.

27. Chang AM, Smith MJ, Galecki AT, Bloem CJ, Halter JB. Impaired beta-cell function in human aging: Response to nicotinic acid-induced insulin resistance. J Clin Endocrinol Metab. 2006;91:3303-3309.

28. Shi-Sheng Zhou, Da Li, Wu-Ping Sun, et al. Nicotinamide overload may play a role in the development of Type 2 diabetes. World $J$ Gastroenterol. 2009;15:5674-5684.

29. Pan J, Lin M, Kesala RL, van J, Charles MA. Treatment of the atherogenic lipid profile and Lp (a) in diabetes. Diabetes Obes Metab. 2002;4:255-261.

30. Trinder F. Estimation of blood glucose. Ann Clin Biochem. 1969;6:24.

31. Steihi A. Reflotron bilirubin. Fortschr Med. 1982;100:842.

32. Heins M. In vitro test for quantitative determination of the total activity of alkaline phosphatase from blood serum or plasma using refloton. Eur J Clin Chem Biochem.1995;33:231.

33. Reitman S, Frankel S. A colorimetric method for the determination of serum glutamic oxalacetic and glutamic pyruvic transaminases. Am J Clin Pathol. 1957;28:56-63.

34. Conget JI, Sarri Y, González-Clemente JM, Casamitjana R, Vives M, Gomis R. Deleterious effect of dithizone-DMSO staining on insulin secretion in rat and human pancreatic islets. Pancreas. 1994;9:157-160.

35. Goldberg ED, Eshchenko EA. Mechanism of phasic fluctuations of glycemia after administration of diabetogenic substances. Probl Endokrinol (Mosk). 1990;35:78-80.

36. Zdravka M, Natalia V, Guangping S, Bonner W, Moore A. In vivo multimodal imaging of transplanted pancreatic islets. Nat Protoc. 2006;1:429-435.

37. Rerup CC. Drugs producing diabetes through damage of the insulin secreting cells. Pharmacol Rev. 1970;22:485-518.

38. Wunderbaldinger P, Josephson L, Weissleder R. Cross linked iron oxides (CLIO): A new platform for the development of targeted MR contrast agents. Acad Radiol. 2002;9:S304-S306.

39. Goldberg ED, Eshchenko VA, Bovt VD. Zinc contents of pancreatic islets in animals of various species after administration of diabetogenic agent, dithizone. Biull Eksp Biol Med. 1992;113:53-55.

40. Latha M, Pari L. Preventive effects of Cassia auriculata L. flowers on brain lipid peroxidation in rats treated with streptozotocin. Mol Cell Biochem. 2003;243:23-28.

41. Ananthan R, Latha M, Ramkumar KM, Pari L, Baskar C, Narmatha B. Antidiabetic Effect of Gymnema montanum leaves: Effect on lipid peroxidation induced oxidative stress in experimental diabetes. Nutrition. 2004;6:379-386. 
42. Szkudelski T. The mechanism of alloxan and streptozotocin action in b cells of the rat pancreas. Physiol Res. 2001;50:536-546.

43. Baynes JW. Reactive oxygen in the aetiology and complications of diabetes. In: Ioannidis C, Flatt PR, editors. Drug, Diet and Disease, Mechanistic Approach to Diabetes. Volume 2. Hertfordshire: Ellis Horwood; 1995.

44. Debbie A, Lawlor D, Sattar N, Smith GD, Ebrahim S. The associations of physical activity and adiposity with alanine aminotransferase and gamma-glutamyltransferase. Am J Epidemiol. 2005;16:1081-1088.

45. Sampathkuma K, Selvam M, Sooraj S, Gowthaman M, Ajeshkumar R. Extended release nicotinic acid a novel oral agent for phosphate control. Int Urol Nephrol. 2006;38:171-174.

46. Kane MP, Hamilton RA, Addesse E, Busch RS, Bakst G. Cholesterol and glycemic effects of Niaspan in patients with Type 2 diabetes. Pharmacotherapy. 2001;21:1473-1478.
47. Grundy SM, Vega GL, McGovern ME, et al. Diabetes Multicenter Research Group: Efficacy, safety, and tolerability of once-daily niacin for the treatment of dyslipidemia associated with Type 2 diabetes: Results of the assessment of diabetes control and evaluation of the efficacy of Niaspan trial. Arch Intern Med. 2002;162:1568-1576.

48. Elam MB, Hunninghake DB, Davis KB, et al. Effect of niacin on lipid and lipoprotein levels and glycemic control in patients with diabetes and peripheral arterial disease: The ADMIT study: a randomized trial. Arterial Disease Multiple Intervention Trial. JAMA. 2000;284:1263-1270.

\section{Publish your work in this journal}

The Journal of Experimental Pharmacology is an international, peerreviewed, open access journal publishing original research, reports, reviews and commentaries on all areas of laboratory and experimental pharmacology. The manuscript management system is completely online and includes a very quick and fair peer-review system.

\section{Dovepress}

Visit http://www.dovepress.com/testimonials.php to read real quotes from published authors. 